\title{
Trends and Issues in the Self-Esteem of Individuals with Autism Spectrum Disorder
}

\author{
Shuhei Ogawa ${ }^{1, *}$ and Michio Kojıma ${ }^{2}$ \\ ${ }^{1}$ Saitama Prefectural Moroyama Special Needs School, Japan \\ ${ }^{2}$ Faculty of Human Sciences, University of Tsukuba, Japan
}

\begin{abstract}
Previous studies $(N=41)$ on the self-esteem of individuals with autism spectrum disorder (ASD) were reviewed, and future issues were investigated. The results of past studies examining the self-esteem level of ASD and typically developing individuals have been inconsistent. Individual differences in the self-esteem level of ASD individuals might be larger than those of typically developing individuals. Moreover, studies on the support for improving the self-esteem of ASD individuals have indicated that although various types of support have been provided, effective support methods have not been developed to date. For the clarification of the self-esteem of ASD individuals, the accumulation of studies on self-esteem from the perspectives of its "stability and level," as well as its "contingency," is required in the future. Furthermore, support for ASD children is crucial to prevent the decline in their self-esteem that starts from the upper grades of elementary school.
\end{abstract}

Key Words: autism spectrum disorder, self-esteem, level of self-esteem

\section{Introduction}

To date, self-esteem has been examined in different psychological studies. Although different definitions of self-esteem are proposed by distinct researchers, these meanings have the following common perspective: self-esteem is a general, affirmative evaluation of the self, i.e., a person with a high self-esteem level feels that he/she is a good person or a valuable existence (Endo, 2013). Ito and Kodama (2005) indicated that self-esteem facilitates subjective well-being, which is the subjective sense of own emotional conditions, as well as psychological well-being, which is the sense of the significance of the life of a person. As described above, self-esteem plays an important role in leading a meaningful life.

Conversely, certain researchers have confirmed that self-esteem might not be as effective as generally expected. Baumeister, Campbell, Krueger, and Vohs (2003) conducted a large-scale review and suggested

\footnotetext{
* Corresponding Author

Mailing Address: 1024-1 Kawakado, Moroyama-machi, Irumagun, Saitama 350-0436, Japan

E-mail Address: shuhei.ogawa77@gmail.com

Received October 15, 2018, Accepted October 19, 2019

DOI: 10.6033 /specialeducation. 8.63
}

that sufficient causal relationships have not been demonstrated between self-esteem and school performance, job and task performance, and interpersonal relationships, among others, and that insufficient evidence is available on the effectiveness of self-esteem. In addition, a high self-esteem level could even have negative outcomes, such as causing increased aggressiveness toward others when the ego is threatened.

Thus, the positive, and negative aspects of the self-esteem of typically developing individuals have been extensively examined to date. Self-esteem is indispensable to adaptation and psychological health (Nakama, 2013) and closely related to the mental health, social adaptation, and success of a person (Zeigler-Hill, 2013). Therefore, people with autism spectrum disorder (ASD), who have difficulties in social adaptation, might have low self-esteem. Investigating the characteristics of self-esteem in people with ASD might be useful for developing the methods of supporting them to improve their psychological health and social adaptation. Volkmar, Sparrow, Goudreau, Cicchetti, Paul, and Cohen (1987) compared a group of ASD individuals and that of non-ASD individuals using the Vineland Adaptive Behavior Scales. The results verified that the former more often had deficits in adaptive social behaviors and showed significantly lower scores in 
building interpersonal relationships, as well as coping skills, among others. Moreover, adolescents with ASD indicated significantly more loneliness compared with their typically developing classmates (Locke, Ishijima, Kasari, \& London, 2010). By contrast, adults with ASD who have higher self-esteem feel less loneliness (Mazurek, 2014), suggesting that self-esteem might be related to decreased loneliness in individuals with ASD. Mazurek (2014) also elucidated that adults with ASD with higher self-esteem also reported higher life satisfaction. Individuals with ASD, who tend to have a stronger sense of loneliness compared with typically developing individuals, must be supported to ensure that their self-esteem does not decline.

International studies have investigated the selfesteem of individuals with ASD, starting with the study by Capps, Sigman, and Yirmiya (1995). Consequently, findings on self-esteem levels using different scales and on diverse support methods have been accumulated.

Beppu (2010a) validated that children with highfunctioning autism (HFA) aged over 9-10 years of age tend to have increased loneliness and anxiety when they do not have peers or when they are bullied, leading to a decline in their self-esteem. Around this age, they tend to care excessively about how their peers evaluate them. Moreover, reduced self-esteem tends to cause problem behaviors, including secondary symptoms (Beppu, 2010a). Furthermore, maintaining high self-esteem is a factor that enables HFA individuals to continue working after adolescence (Beppu, 2010a).

This study reviewed studies on the self-esteem of individuals with ASD and identified their achievements and problems. Moreover, the effective methods of supporting people with ASD for improving their self-esteem were discussed.

Although the definitions of self-esteem have been different depending on the researchers, they have the following common perspective: self-esteem is a general, affirmative evaluation of the self, such that a person with high self-esteem feels that he/she is a good person or a valuable existence (Endo, 2013). The concept of self-esteem is distinguished from self-evaluation, which is made in relation to a specific field (Kojima, 2012). In this article, self-esteem is regarded as a general evaluation and distinguished from selfevaluation.

\section{Method}

The Japanese articles were searched using "CiNii," which is a database maintained by the National Institute of Informatics, by combining keywords such as "ASD," "autism," "pervasive developmental disorders," "Asperger syndrome," and, "self-esteem," "selfevaluation," and "QOL." The English peer-reviewed articles were searched using "Web of Science," "PubMed," "ERIC," and "PsycINFO"1) by combining keywords such as "ASD," "autism," and "self-esteem" on February 11, 20192). The articles that were judged to be unrelated to the self-esteem of individuals with ASD were excluded after reading the abstracts. Moreover, the published dissertations and conference presentations were also excluded. The articles that used the term "self-esteem" with a significantly different meaning from the definition of Endo (2013), i.e., a general, affirmative evaluation of oneself, were also excluded from the analysis. Among articles dealing with the support for improving the self-esteem of individuals with ASD, only those that assessed changes in self-esteem by an intervention were included in this review. In addition, when the assessment of the intervention effect was made by mixing ASD and non-ASD individuals (typically developing individuals and individuals with other disabilities), studies using less than $80 \%$ of the samples of ASD individuals were excluded from the analysis subjects. Consequently, 41 articles were analyzed.

\section{Results and Discussion}

\section{Changes in the Number of Studies on the Self-Esteem of Individuals with ASD}

Studies on the self-esteem of individuals with ASD have started from the 1990s, and since then, the number of related publications has increased. Only one article on this topic was published in the 1990s, while six articles were published from 2001 to 2010, and 34 articles were published from 2011 to 2018.

\section{Studies on the Self-Esteem Level of Individuals with ASD}

Table 1 shows a list of the study contents related to the self-esteem level of individuals with ASD. To date, various studies have been conducted internationally on this topic although their results have been inconsistent. Certain studies have indicated 
Trends and Issues in the Self-Esteem of Individuals with Autism Spectrum Disorder

Table 1 Content of Studies on the Level of Self-Esteem in ASD Individuals

\begin{tabular}{|c|c|c|c|c|c|}
\hline Author & Scale & Age or Grade & Paticipant & Number & Significance \\
\hline \multicolumn{6}{|l|}{ SPPC } \\
\hline \multirow[t]{2}{*}{ Capps et al. (1995) } & \multirow[t]{2}{*}{ PCSC $^{\text {a) }}$ (Harter, 1982) } & $9 y \sim 16 y$ & Children with HFASD & $18(\mathrm{M} 15, \mathrm{~F} 3)$ & \multirow[t]{2}{*}{ Significantly low } \\
\hline & & $9 y \sim 14 y$ & Normally developing children & $20(\mathrm{M} 17, \mathrm{~F} 3)$ & \\
\hline \multirow[t]{2}{*}{ Nomura et al. (2012) } & \multirow{2}{*}{$\begin{array}{l}\text { PCSC }^{\text {a) }} \text { (Harter, 1982; } \\
\text { Sakurai, 1983) }\end{array}$} & $1 \mathrm{G} \sim 9 \mathrm{G}$ & Children with HFPDD & 45 & \multirow[t]{2}{*}{ NS } \\
\hline & & $1 \mathrm{G} \sim 9 \mathrm{G}$ & $\begin{array}{l}\text { Children who are typically } \\
\text { developed }\end{array}$ & 281 & \\
\hline \multirow[t]{4}{*}{ Nagai et al. (2018) } & \multirow{4}{*}{$\begin{array}{l}\text { PCSC }^{\text {a) }} \text { (Harter, 1982; } \\
\text { Sakurai, 1992) }\end{array}$} & $6 y \sim 12 y$ & ASD group ${ }^{b)}$ & $91(\mathrm{M} 70, \mathrm{~F} 21)$ & \multirow[t]{4}{*}{$\mathrm{NS}^{\mathrm{c})}$} \\
\hline & & $6 y \sim 12 y$ & Nephrotic syndrome group & 52 (M33, F19) & \\
\hline & & $6 y \sim 12 y$ & Asthma group & $84(\mathrm{M} 50, \mathrm{~F} 34)$ & \\
\hline & & $6 y \sim 12 y$ & Healthy controls & 694 (M331, F363) & \\
\hline \multirow{2}{*}{$\begin{array}{l}\text { Bauminger et al. } \\
\quad(2004)\end{array}$} & \multirow[t]{2}{*}{ SPPC (Harter, 1985) } & $8 y \sim 17 y$ & Individuals with HFASD & $16(\mathrm{M} 15, \mathrm{~F} 1)$ & \multirow[t]{2}{*}{ NS } \\
\hline & & $8 y \sim 16 y$ & Typically developing individuals & $16(\mathrm{M} 15, \mathrm{~F} 1)$ & \\
\hline \multirow[t]{2}{*}{$\begin{array}{l}\text { Williamson et al. } \\
\text { (2008) }\end{array}$} & \multirow[t]{2}{*}{ SPPC (Harter, 1985) } & $11 y \sim 15 y$ & $\begin{array}{l}\text { Adolescents with Asperger } \\
\text { syndrome }\end{array}$ & 19 (M16, F3) & \multirow[t]{2}{*}{ NS } \\
\hline & & $11 \mathrm{y} \sim 15 \mathrm{y}$ & Typically developing adolescents & 19 (M16, F3) & \\
\hline \multirow[t]{3}{*}{ Oka et al. (2010) } & \multirow{3}{*}{$\begin{array}{l}\text { SPPC (Harter, 1985; } \\
\text { Maeshiro, 2000) }\end{array}$} & $9 y \sim 15 y$ & Children with HFPDD & $15(\mathrm{M} 14, \mathrm{~F} 1)$ & \multirow[t]{3}{*}{ NS } \\
\hline & & $14 y \sim 17 y$ & $\begin{array}{l}\text { Autism children with mental } \\
\text { retardation }\end{array}$ & 10 & \\
\hline & & $4 \mathrm{G} \sim 8 \mathrm{G}$ & Typically-developed children & 313 & \\
\hline \multirow[t]{2}{*}{ Miyachi et al. (2013) } & \multirow{2}{*}{$\begin{array}{l}\text { SPPC (Harter, 1985; } \\
\text { Miyachi et al., 2013) }\end{array}$} & $4 \mathrm{G} \sim 6 \mathrm{G}$ & Children with HFPDD & $20(\mathrm{M} 13, \mathrm{~F} 7)$ & \multirow[t]{2}{*}{ NS } \\
\hline & & $4 \mathrm{G} \sim 6 \mathrm{G}$ & Typically developing children & $146(\mathrm{M} 69, \mathrm{~F} 77)$ & \\
\hline \multicolumn{6}{|l|}{ SPPA } \\
\hline \multirow[t]{2}{*}{ Jamison et al. (2015) } & \multirow{2}{*}{$\begin{array}{l}\text { SPPA (Harter, 1988; } \\
\text { Harter, 2012b) }\end{array}$} & $14 \mathrm{y} \sim 19 \mathrm{y}$ & Adolescent females with HFASD & $23^{\mathrm{d})}(\mathrm{F} 23)$ & \multirow[t]{2}{*}{ Significantly low } \\
\hline & & $14 \mathrm{y} \sim 19 \mathrm{y}$ & Adolescent females without ASD & $29^{\mathrm{e})}(\mathrm{F} 29)$ & \\
\hline \multirow[t]{2}{*}{ Goddard et al. (2017) } & \multirow[t]{2}{*}{ SPPA (Harter, 2012b) } & $13 \mathrm{y} \sim 17 \mathrm{y}$ & Adolescents with $\mathrm{ASD}^{\mathrm{b})}$ & $16(\mathrm{M} 14, \mathrm{~F} 2)$ & \multirow[t]{2}{*}{ Significantly low } \\
\hline & & $13 \mathrm{y} \sim 17 \mathrm{y}$ & Adolescents without ASD & $16(\mathrm{M} 14, \mathrm{~F} 2)$ & \\
\hline Rosenberg Self-Esteem S & cale (RSES) & & & & \\
\hline Maras et al. (2012) & $\begin{array}{l}\text { RSES (Rosenberg, } \\
\text { 1965) }\end{array}$ & $\begin{array}{l}\text { Avg 39.44y } \\
(S D=12.35)\end{array}$ & Adults with HFASD & $32^{\mathrm{f})}(\mathrm{M} 24, \mathrm{~F} 8)$ & NS \\
\hline & & $\begin{array}{l}\text { Avg } 42.03 y \\
(S D=12.45)\end{array}$ & Non-ASD typical adults & $30^{\mathrm{g})}(\mathrm{M} 22, \mathrm{~F} 8)$ & \\
\hline Kojima et al. (2013) & RSES (Rosenberg, & $4 \mathrm{G} \sim 6 \mathrm{G}$ & Children with HFPDD & 36 (M36) & NS \\
\hline & $\begin{array}{l}\text { 1965; Yamamoto, } \\
\text { Matsui, \& Yamanari, } \\
\text { 1982; Kojima et al., } \\
\text { 2013) }\end{array}$ & $4 \mathrm{G} \sim 6 \mathrm{G}$ & Typically developing children & 202 (M202) & \\
\hline Cooper et al. (2017) & $\begin{array}{l}\text { RSES (Rosenberg, } \\
\text { 1965) }\end{array}$ & $\begin{array}{l}\text { Avg 32.7y } \\
(S D=12.6)\end{array}$ & People with ASD ${ }^{\text {b) }}$ & $272(\mathrm{M} 53 \%, \mathrm{~F} 47 \%)$ & Significantly low \\
\hline & & $\begin{array}{l}\text { Avg } 34.2 y \\
(S D=12.2)\end{array}$ & Typically developing people & 267 (M47\%, F53\%) & \\
\hline $\begin{array}{l}\text { McChesney et al. } \\
\text { (2018) }\end{array}$ & $\begin{array}{l}\text { RSES }^{\text {h) }} \text { (Rosenberg, } \\
1965)\end{array}$ & $\begin{array}{l}\text { Avg } 10.67 \mathrm{y} \\
(S D=0.49)\end{array}$ & Children with ASD & 408 (M79\%, F21\%) & Significantly low \\
\hline & & $\begin{array}{l}\text { Avg } 10.68 \mathrm{y} \\
(S D=0.48)\end{array}$ & Children without ASD & $\begin{array}{l}12,877(\mathrm{M} 50 \%, \\
\mathrm{F} 50 \%)\end{array}$ & \\
\hline Chandler et al. (2018) & $\begin{array}{l}\text { RSES (Rosenberg, } \\
\text { 1965) }\end{array}$ & $\begin{array}{l}\text { Avg 26.50y } \\
(S D=11.30)\end{array}$ & Adults with ASD & $26(\mathrm{M} 19, \mathrm{~F} 7)$ & Significantly low \\
\hline & & $\begin{array}{c}\text { Avg } 24.87 y \\
(S D=7.33)\end{array}$ & Typically developing adults & $26(\mathrm{M} 16, \mathrm{~F} 10)$ & \\
\hline
\end{tabular}


Table 1 Continued

\begin{tabular}{|c|c|c|c|c|c|}
\hline Author & Scale & Age or Grade & Paticipant & Number & Significance \\
\hline \multicolumn{6}{|l|}{ Other scales } \\
\hline \multirow[t]{4}{*}{ Ichikado et al. (2008) } & \multirow{4}{*}{$\begin{array}{l}\text { Self-Esteem Scale } \\
\text { (Inoue, 1986; Ota } \\
\text { \& Nagasawa, 2004) }\end{array}$} & $13 \mathrm{y} \sim 29 \mathrm{y}^{\mathrm{i})}$ & Individuals with HFASD & $10^{\mathrm{i})}$ & \multirow[t]{4}{*}{ NS } \\
\hline & & $13 \mathrm{y} \sim 29 \mathrm{y}^{\mathrm{i})}$ & $\begin{array}{l}\text { Individuals with Asperger } \\
\text { syndrome }\end{array}$ & $10^{\mathrm{i})}$ & \\
\hline & & $13 \mathrm{y} \sim 29 \mathrm{y}^{\mathrm{i})}$ & Individuals with $\mathrm{LD}$ or ADHD & $9^{\text {i) }}$ & \\
\hline & & $13 y \sim 29 y$ & Typically developing individuals & $30(\mathrm{M} 23, \mathrm{~F} 7)$ & \\
\hline \multirow[t]{2}{*}{$\begin{array}{l}\text { McCauley et al. } \\
\quad(2017)\end{array}$} & \multirow{2}{*}{$\begin{array}{l}\text { Marsh Self-Description } \\
\text { Questionnaire-II } \\
\text { (Marsh, 1992) Lifespan } \\
\text { Self-Esteem Scale) } \\
\text { (Harris, Donnellan, } \\
\text { \& Trzesniewski, 2017) }\end{array}$} & $\begin{array}{l}\text { Avg } 12.75 y \\
(S D=2.22)\end{array}$ & Youth with $\mathrm{ASD}^{\mathrm{b})}$ & 39 (M33, F6) & \multirow[t]{2}{*}{ Significantly low } \\
\hline & & $\begin{array}{l}\text { Avg } 12.82 y \\
(S D=2.26)\end{array}$ & Typically developing youth & $34(\mathrm{M} 22, \mathrm{~F} 12)$ & \\
\hline
\end{tabular}

Notes. $\mathrm{y}=$ year, $\mathrm{G}=\mathrm{Grade}$, Avg=Average, $S D=$ Standard deviation, $\mathrm{M}=$ Male, $\mathrm{F}=$ Female, NS=Not significant, HFPDD=High functioning pervasive developmental disorders, HFASD=High functioning ASD, LD=Learning disabilities, ADHD=Attention-deficit/hyper activity disorder.

a) Here, PCSC (Perceived Competence Scale for Children) is used as the same as SPPC.

b) No intellectual disabilities.

c) Self-esteem of the ASD group was significantly lower than self-esteem of the Asthma group. However, there were no significant differences when compared to Healthy controls. Therefore, we described it as NS.

d) The number of valid responses $=15$

e) The number of valid responses $=22$

f) The number of valid responses $=30$

g) The number of valid responses $=27$

h) A brief version consisting of five question items (the original version included 10 items).

i) The mean age and $S D$ of Individuals with HFASD, Individuals with Asperger syndrome, Individuals with LD or ADHD were 20.9 \pm 5.1 . However, one participant among 10 Individuals with LD or ADHD refused to respond, and his/her age was unknown. Therefore, the actual mean age and $S D$ is unknown. As for the gender of individuals with HFASD, Individuals with Asperg syndrome, and Individuals with LD or ADHD $(N=30)$, the number of men was 23 and that of women was 7 . However, the accurate gender ratio was unknown because the gender of one participant that refused to respond was unknown.

j) The level of significance was $p<.10$.

that there were no significant differences in selfesteem between individuals with ASD and typically developing individuals (Bauminger, Shulman, \& Agam, 2004; Ichikado, Sumio, \& Abe, 2008; Kojima \& Noutomi, 2013; Maras \& Bowler, 2012; Miyachi \& Kojima, 2013; Nagai, Uemura, Kaneko, Kanda, Gotoh, Nakagawa, Uzuyama, Nomura, \& Iwasa, 2018; Nomura, Beppu, \& Tsujii, 2012; Oka \& Ono, 2010; Williamson, Craig, \& Slinger, 2008). Other studies have indicated that the self-esteem of individuals with ASD was significantly lower than that of typically developing individuals (Capps et al., 1995; Chandler, Russell, \& Maras, 2018; Cooper, Smith, \& Russell, 2017; Goddard, O’Dowda, \& Pring, 2017; Jamison \& Schuttler, 2015; McCauley, Harris, Zajic, Swain-Lerro, Oswald, McIntyre, Trzesniewski, Mundy, \& Solomon, 2017; McChesney \& Toseeb, 2018).
Studies on self-esteem level in individuals with ASD have been classified into two types on the basis of the scales used in these studies and the developmental stages of individuals with ASD.

The classification based on the scales has resulted in four types of studies: those using the SelfPerception Profile for Children (SPPC) developed by Harter $(1985 ; 2012 a)$, those employing the SelfPerception Profile for Adolescents (SPPA) developed by Harter $(1988 ; 2012 b)$, those utilizing the Rosenberg Self-Esteem Scale (1965), and those applying other scales.

The SPPC is a scale for children consisting of 36 question items assessing five types of competence, i.e., "Scholastic Competence," "Athletic Competence," "Social Competence," "Physical Appearance," and "Behavioral Conduct," as well as "Global Self-Worth (Self-Esteem).” According to Harter (1985; 2012a) 
"Global Self-Worth (Self-Esteem)" is a global judgment of self-worth as a person. Harter $(1985 ; 2012 a)$ indicated that "Global Self-Worth (Self-Esteem)" is not an overall evaluation composed of the synthesis of specific evaluations, which is similar to the Rosenberg Self-Esteem Scale because self-esteem is assessed by focusing on global self-esteem. However, the SPPC is different from the Rosenberg Self-Esteem Scale because the wording of the SPPC is more appropriate for children (Harter, 2012a).

Conversely, topics other than global self-worth are concerned with the content of specific fields. Therefore, they can be included in the domain of selfevaluation. This article mainly examined global selfworth, which is consistent with the concept of selfesteem. Previous studies on ASD children using the SPPC have reported significant differences between ASD and typically developing children in the following aspects that can be considered self-evaluations, which include "Social Acceptance" and "Athletic Competence" (Bauminger et al., 2004), "Social Competence" and "Physical Competence" (Capps et al., 1995), "Peer Likability" and "Social Acceptance" (Williamson et al., 2008), and "Social Acceptance (Nomura et al., 2012), among others. Although most of these studies agree that ASD children have lower social acceptance compared with typically developing children, they are not always consistent regarding other characteristics. These inconsistencies might be caused by differences in the chronological age of the participants. Careful analysis of these differences is required because no clear differences emerged in the chronological age of the participants in previous studies.

Seven studies have compared the self-esteem levels between ASD and typically developing individuals using the SPPC. Among them, six studies have indicated no significant differences (Bauminger et al., 2004; Miyachi \& Kojima, 2013; Nagai et al., 2018; Nomura et al., 2012; Oka et al., 2010; Williamson et al., 2008), and one study has indicated that the selfesteem of ASD individuals was significantly lower than that of typically developing individuals (Capps et al., 1995). Generally, no significant differences in self-esteem between ASD individuals and typically developing individuals have been demonstrated in studies using the SPPC.

The SPPA is a scale for adolescents consisting of 45 question items assessing the five types of competencies in the SPPC and three domains, i.e., "Job Competence," "Romantic Appeal," and "Close Friendship," as well as "Global Self-Worth (SelfEsteem)." Similar to the SPPC, the SPPA is comparable with the idea of the Rosenberg Self-Esteem Scale in that self-esteem is assessed by focusing on global self-esteem (Harter, 2012b). However, the SPPA is different from the Rosenberg Self-Esteem Scale in that the wording of the former is more appropriate for adolescents (Harter, 2012b).

Two studies have compared the self-esteem levels between ASD and typically developing individuals (Goddard et al., 2017; Jamison \& Schuttler, 2015) using the SPPA. Both studies have indicated that the self-esteem of ASD individuals was significantly lower than that of typically developing individuals.

The Rosenberg Self-Esteem Scale (1965) consisting of 10 items is a representative scale for assessing self-esteem, which has been used for over 50 years. Rosenberg (1965) indicated that self-esteem is a positive or a negative attitude toward the self, which can have two different meanings: "Very good" and "Good enough." The first of these meanings includes superiority to others, whereas the second meaning implies that an individual feels that he or she is a person of worth, without comparing with others. Additionally, people do not simply accept themselves and desire to overcome their deficiencies (Rosenberg, 1965). The Rosenberg Self-Esteem Scale (1965) has been developed on the basis of the idea of "Good enough."

Five studies have compared self-esteem between ASD and typically developing individuals using the Rosenberg Self-Esteem Scale. Among them, two studies have not shown significant differences (Kojima \& Noutomi 2013; Maras \& Bowler, 2012), while three studies have indicated significantly lower self-esteem in ASD individuals compared with typically developing individuals (Chandler et al., 2018; Cooper et al., 2017; McChesney \& Toseeb, 2018).

Two studies have compared the self-esteem levels ASD and typically developing individuals using other scales. Ichikado et al. (2008) did not report significant differences, and McCauley et al. (2017) indicated significantly lower self-esteem in ASD individuals compared with typically developing individuals.

The self-esteem scale developed by Ota and Nagasawa (2004), which was used by Ichikado et al. (2008), has been repeatedly revised. Initially, Inoue (1986) defined self-esteem as "the sense of 
self-value that is the basis for living one's own life true to oneself" and developed a scale by referring to Coopersmith (1967), Inoue (1985), and Kajita (1980). Thereafter, Ota and Nagasawa (2004) revised the scale (Inoue, 1986) by modifying its expressions so that third-grade elementary school students could easily understand the items and developed a scale consisting of 42 items by excluding false items.

Marsh Self-Description Questionnaire-II (SDQ-II; Marsh, 1992), which is used by McCauley et al. (2017), is a scale consisting of 102 items for junior and senior high school students. The 102 items are classified into 11 subscales including, "Physical Abilities," and 10 items among the scales are for assessing self-esteem. This scale was developed on the basis of Rosenberg's (1965) definition of self-esteem as positive and negative attitudes about the self.

The Lifespan Self-Esteem Scale (LSE; Harris, Donnellan, \& Trzesniewski, 2017), which is used by McCauley et al. (2017), is a scale for assessing global self-esteem throughout the life span. Most selfesteem scales cannot assess self-esteem throughout the life span, whereas the LSE can assess the longterm self-esteem through the life span between 5 and 93 years of age. Self-esteem in the LSE is defined as comprehensive and subjective self-evaluation.

As stated above, the results of these studies are inconsistent. Seven studies have suggested significantly lower self-esteem in ASD individuals, while nine studies have not indicated any significant differences, which is slightly more than the former.

However, the above results must be reconsidered for some reasons after considering the sample sizes of ASD individuals in these studies. Among 16 studies, the sample size of 13 studies was approximately $10-40$, that of one study was approximately 90 (Nagai et al., 2018), and two studies had a sample size of over a hundred participants (Cooper et al., 2017; McChesney \& Toseeb, 2018). Cooper et al. (2017) compared the self-esteem levels between ASD individuals $(N=272$, mean age $=32.7)$ without intellectual disabilities and typically developing people $(N=267$, mean age $=34.2$ ), whereas McChesney \& Toseeb (2018) compared the self-esteem levels between children with ASD $(N=408$, mean age $=10.67)$ and those without ASD $(N=12,877$, mean age $=10.68)$. Both studies reported that the self-esteem of individuals with ASD was significantly lower than typically developing individuals. These two studies should be perceived differently from other studies that had only a few dozen participants. The number of studies showing lower self-esteem in ASD individuals is relatively small; however, the small sample size of these studies casts doubt on the conclusion of most studies suggesting that no significant differences emerge in self-esteem between ASD and typically developing individuals.

Why have the results of previous studies been inconsistent? McCauley et al. (2017) regarded that differences among the scales were one reason for inconsistent results among different studies. However, certain studies have shown different results even when using the same scale. Moreover, age and gender differences were not regarded as a reason for different results because divergent results were obtained also with participants of similar age and gender.

Two issues have been suggested as the reasons for these inconsistencies. First, obtaining significant differences is difficult because of the small sample size of some studies and because the participants were limited to individuals with ASD who could respond to questionnaires. Second, individual differences significantly affect the self-esteem level of ASD individuals (Kojima \& Noutomi, 2013). The comparison of the standard deviation $(S D)$ of self-esteem scores between ASD and typically developing individuals indicated that the $S D$ of the self-esteem scores of ASD individuals was higher in nine studies (the number of scales was 10) (Bauminger et al., 2004; Capps et al., 1995; Chandler et al., 2018; Cooper et al., 2017; Jamison \& Schuttler, 2015; Maras \& Bowler, 2012; McCauley et al., 2017; McChesney \& Toseeb, 2018; Nagai et al., 20183)), whereas in two studies, ASD individuals had lower $S D$ of self-esteem scores than typically developing individuals (Ichikado et al., 2008; Williamson et al., 2008). Moreover, one study indicated gender differences in the $S D$ level of self-esteem scores, i.e., the $S D$ of males with ASD was higher than typically developing males, whereas the $S D$ of females with ASD was lower than typically developing females (Miyachi \& Kojima, 2013). The above results suggest that individual differences in the self-esteem level of ASD individuals might be larger than those of typically developing individuals.

As for developmental stages, which is the other type of the classification of studies on the self-esteem level of ASD individuals, four stages have been 
assumed on the basis of the following developmental stages: childhood, adolescence, adulthood, and old age. According to Koyasu (2013), childhood consists of elementary school, while adolescence is between junior high school and the late twenties, adulthood is after the thirties, and old age is over 65 years.

Four studies have focused only on the childhood of individuals with ASD. Among them, three studies have revealed no significant differences in selfesteem between ASD children and typically developing children (Kojima \& Noutomi, 2013; Miyachi \& Kojima, 2013; Nagai et al., 2018), while one study has indicated significantly lower self-esteem in ASD children compared with typically developing children (McChesney \& Toseeb, 2018). Three studies have focused only on the adolescence of individuals with ASD. Among them, one study has exhibited no significant differences in self-esteem between ASD adolescents and typically developing adolescents (Ichikado et al., 2008), while two studies have indicated significantly lower self-esteem in ASD adolescents compared with typically developing adolescents (Goddard et al., 2017; Jamison \& Schuttler, 2015). No studies have focused only on the adulthood or old age of individuals with ASD.

Six studies have investigated the childhood and adolescence of individuals with ASD (Bauminger et al., 2004; Capps et al., 1995; McCauley et al., 2017; Nomura et al., 2012; Oka \& Ono, 2010; Williamson et al., 2008), and three studies have examined adolescence and adulthood (Chandler et al., 2018; Cooper et al., 2017; Maras \& Bowler, 2012). Among them, only one study has investigated the aspects of self-esteem on the basis of the developmental stage (Nomura et al., 2012). Nomura et al. (2012) reported that the self-esteem levels in ASD individuals tended to decline from the first to the ninth grade.

Robins, Trzesniewski, Tracy, Gosling, and Potter (2002) conducted a cross-sectional study on the self-esteem of typically developing individuals $(N=326,641)$ aged 9 to 90 years. The results indicated that "self-esteem levels were high in childhood, dropped during adolescence, rose gradually throughout adulthood, and declined sharply in old age."

Synthesizing these results suggests the following hypothesis. The self-esteem of ASD individuals is nearly identical or a little lower than typically developing individuals. The self-esteem of ASD individuals is somewhat high during childhood and declines from childhood to adolescence.

Several factors could lead to the gradual decline in the self-esteem of ASD children from lower to higher grades of elementary school and junior high school and eventually slightly decrease the self-esteem of ASD children compared with typically developing children. First, ASD children realize differences between themselves and others and develop doubts about themselves (Tanaka, Hirosawa, Takiyoshi, \& Yamazaki, 2006). They also make negative evaluations of themselves because of these differences. Tanaka et al. (2006) conducted a study on the selfdoubts of pervasive developmental disorder (PDD) children and reported that $69 \%$ of the participants had doubts about their environment and that $46 \%$ had doubts about their characteristics. Moreover, lower grade elementary school students have doubts about their "special environment," which has resulted from their disabilities. Conversely, higher graders in elementary school had more doubts about their internal characteristics. Their self-esteem might therefore decline because of negative evaluations caused by doubts. The information they have about their diagnosis could also lead to doubts (Tanaka et al., 2006), which could influence the self-esteem of children (Kojima, 2012). Consequently, taking sufficient care is essential to ensure that self-esteem is maintained when informing PDD children about their diagnosis.

ASD children acquire theory of mind (ToM) when their verbal mental age is over nine years (Happé, 1995). Children with HFA who have acquired ToM tend to be more conscious about what other people think of them than typically developing children (Beppu, 2010b). The self-esteem of ASD children without intellectual disabilities is lower when their ToM task score is higher (McCauley et al., 2017). The understanding of ASD children about others starts to develop after approximately nine years old, and they become highly conscious of what others think about them. Their self-esteem might also start to decline.

ASD children are bullied more than typically developing individuals (Chandler et al., 2018), which could also result in low self-esteem. Doubts about the self, the development of understanding about others through acquiring ToM, being informed about the diagnosis, and experiences of being bullied might all affect the reduced self-esteem of ASD children compared with typically developing children.

However, whether or not the above factors cause a 
decline in the self-esteem of ASD children is unclear because previous studies have not indicated distinct differences in the self-esteem levels between ASD and typically developing children. ASD children can possibly maintain a self-esteem level that is identical to that of typically developing children if they are supported appropriately to maintain their self-esteem, such as not denying the differences between ASD children and typically developing children, preventing bullying, and being considerate when informing them of their diagnosis, among others.

The hypothesis that the self-esteem of ASD individuals is similar to typically developing individuals suggests that the self-esteem of ASD individuals gradually increases in adulthood and sharply declines in old age to a similar or somewhat lower level than that of typically developing individuals. Why have only a few studies been conducted on self-esteem of ASD individuals after adulthood? This could be because secondary symptoms appear between higher grades of elementary school and adolescence, and consequently, researchers might not have investigated adults.

Most previous studies on the self-esteem level of individuals with ASD have focused on childhood and adolescence, and only a few studies have investigated self-esteem in adulthood and old age. Eight studies have been conducted without categorizing the participants into developmental stages. The self-esteem levels of individuals with ASD based on their developmental stage have been insufficiently investigated to date and remain an issue for investigating in future studies.

\section{Studies on the Support for Improving the Self- Esteem of Individuals with ASD}

Table 2 shows the content of studies on the support provided to improve the self-esteem of individuals with ASD. Among 16 studies, 14 (87.5\%) indicated an increase in self-esteem after the intervention, and four $(25.0 \%)$ revealed significant statistical differences resulting from the intervention. Among support methods regarding which plural articles have been published, the "Mentoring program" has shown the most significant differences in self-esteem resulting from the intervention (50\%, one study among two).

One of the studies that indicated significant differences in the self-esteem of ASD individuals between before and after providing interventions was conducted by Hillier et al. (2018), who introduced the "Connections program." In this program, university students with ASD $(N=52)$ were divided into several groups consisting of 5-7 members, and a one-hour intervention was conducted once a week for seven weeks. Issues that cause problems for ASD students in campus life were selected by the program director, including "academic skills," "interpersonal communication and relationships," "working in groups," and "time and stress management," among others. Students with ASD interacted with one another in a small group. Results indicated that the self-esteem of ASD students increased significantly as a result of the intervention. Hillier et al. (2018) suggested that students with ASD who participated in the program recognized that they had the required abilities for university education and felt that they could solve problems, which resulted in an improvement in their self-esteem.

By contrast, significant differences in self-esteem were not shown by providing "Cognitive behavior therapy" (No improvements were described in three studies) and "Metacognitive training" (No improvements were described in two studies). An increase in self-esteem resulting from interventions was indicated in $87.5 \%$ of previous studies, which is rather high. However, statistically significant differences were shown in only $25.0 \%$ of the studies. Moreover, the number of studies using a specific type of support method has been rather small. "Cognitive behavioral therapy" was used in three studies, which is the largest, whereas "Music intervention" and other methods were used in only one study, which is the smallest. Therefore, inadequate investigations of intervention methods for improving the self-esteem of ASD individuals have emerged.

Four studies on support for improving the selfesteem of ASD individuals in childhood and adolescence conducted from the perspective of developmental stages have demonstrated significant effects before and after the intervention (Bradley, 2016; Hillier et al., 2018; Hillier et al., 2012; Kato et al. al., 2016). Interventions targeting self-esteem might be effective in childhood and adolescence because self-esteem tends to decline from childhood to adolescence (Robins et al., 2002). However, two studies have indicated no significant effects of the intervention (Bruin \& Verheij, 2012; Spain et al., 2017), and 
one of these two studies have been conducted on childhood (Bruin et al., 2012). The participants in the study (Bruin et al., 2012) had a mean age of 8.5 years $(S D=0.5)$, suggesting that the effects of interventions on self-esteem might not be observed in early childhood. Nevertheless, further study is required because factors other than age might have caused this result.

Five studies on individual guidance (Bono et al., 2016; Bradley, 2016; Curtin et al., 2016; Honda, 2003; Turner \& Hammond, 2016) and 11 on group guidance (Bruin et al., 2012; Goodman et al., 2017; Gordon et al., 2015; Henomatsu, 2016; Hesselmark et al., 2014; Hillier et al., 2018; Hillier et al., 2012; Kato \& Fujino, 2016; Morita, 2012; Schiltz et al., 2018; Spain \& Blainey, 2017) have been undertaken to investigate the effects of the type of guidance on improving the self-esteem of individuals with ASD. The results of five of five studies using individual guidance reported positive results (one with a significant difference), whereas nine of 11 studies using group guidance were positive (three with significant differences), which makes determining the relative efficacy of individual or group guidance difficult. This issue should be investigated further in future studies.

The review of studies on the self-esteem of ASD individuals suggests that interventions should be conducted in the period between the upper grades of elementary school and senior high school when their self-esteem tends to decline. Among 16 intervention studies that were reviewed, the participants in nine studies had an approximate mean age of 10-18 years. All these studies provided the evidence of intervention effects. Kawai, Yoshida, Miyamoto, and Yamanaka (2006) reported that higher grades of elementary school are appropriate for conducting interventions to prevent the decline of self-esteem. Therefore, interventions with ASD children might be effective until approximately 18 years of age. Support for preventing the decline of self-esteem in ASD children should be initiated in the upper grades of elementary school.

\section{General Discussion}

\section{Necessity for Studies That Perceive the Self-Esteem of ASD Individuals from Different Perspectives}

This study analyzed investigations of the selfesteem of individuals with ASD. Among them, studies focusing on the self-esteem levels of ASD indi- viduals emerged. However, no studies have examined self-esteem from different perspectives. Correlations exist between self-esteem and problems in externalizing (Donnellan, Trzesniewski, Robins, Moffitt, \& Caspi, 2005). On the other hand, the type of selfesteem that might result in social adaptation has not been sufficiently examined to date. ASD individuals are known to have problems in social adaptation (Volkmar et al., 1987), and examining the type of self-esteem that could be related to social adaptation would be meaningful. By contrast, the self-esteem of typically developing individuals has been examined from many different perspectives. For instance, Kernis, Grannemann, \& Barclay (1989) examined the self-esteem of typically developing individuals from the viewpoint of stability and level and indicated that unstable high self-esteem was associated with a strong propensity to experience anger and hostility, whereas stable high self-esteem was associated with a low propensity to experience these emotions.

Deci and Ryan (1995) classified self-esteem into two types: contingent self-esteem (contingencies of self-worth $)^{4)}$ and true self-esteem. "Contingent selfesteem refers to feelings about oneself that result from matching some standard of excellence or living up to some interpersonal or intrapsychic expectations" (Deci \& Ryan, 1995). Therefore, people sometimes get trapped in self-deception to satisfy contingent self-esteem. By contrast, "true self-esteem is more stable, more securely based in a solid sense of self." (Deci \& Ryan, 1995). Moreover, "people with high true self-esteem, of course, would have goals and aspirations, and they would attempt to accomplish those outcomes by devoting their personal resources to them, often wholeheartedly" (Deci \& Ryan, 1995). True self-esteem is considered more adaptive than contingent self-esteem. True selfesteem is a conceptual proposal, and the method of assessing self-esteem must be examined in the future.

Contingent self-esteem can be divided into two perspectives. The first regards contingent self-esteem as a factor (Deci \& Ryan, 1995; Kernis, 2003), and between-persons differences focus on determining the extent to which the self-esteem of an individual is associated with external factors (Kernis, 2003).

The second perspective regards contingent selfesteem as consisting of multiple factors. Crocker and Wolfe (2001) considered that self-esteem might be contingent on seven factors, i.e., "Approval from 
Table 2 Content of Studies on the Support for Improving Self-Esteem of Individuals with ASD

\begin{tabular}{|c|c|c|c|c|c|c|c|c|}
\hline Content & Author & $\begin{array}{l}\text { Term or } \\
\text { frequency }\end{array}$ & $\begin{array}{l}\text { Guidance } \\
\text { type }\end{array}$ & Age or Grade & Participant & Number ${ }^{a)}$ & Scale & Effect $^{\mathrm{b})}$ \\
\hline \multirow[t]{3}{*}{$\begin{array}{l}\text { Cognitive behavior } \\
\text { therapy }\end{array}$} & $\begin{array}{l}\text { Hesselmark, Plenty, } \\
\text { \& Bejerot (2014) }\end{array}$ & 36 sessions & Group & $\begin{array}{l}\left.\text { Avg } 31.9 y^{c}\right) \\
(S D=8.5)\end{array}$ & $\begin{array}{l}\text { Adults with } \\
\text { ASD }^{\text {d) }}\end{array}$ & 31 & $\begin{array}{l}\text { RSES } \\
\text { (Rosenberg, } \\
1962 \text { ) }\end{array}$ & Effective \\
\hline & $\begin{array}{l}\text { Spain \& Blainey } \\
(2017)\end{array}$ & 8 sessions $^{\mathrm{e})}$ & Group & $\begin{array}{l}\text { Avg } 39 y \\
(\text { Range }=30 y-45 y)\end{array}$ & $\begin{array}{l}\text { Adults with } \\
\text { ASD }^{\text {d) }}\end{array}$ & $4(\mathrm{M} 4)$ & $\begin{array}{l}\text { RSES } \\
\text { (Rosenberg, } \\
1965 \text { ) }\end{array}$ & Nothing \\
\hline & $\begin{array}{l}\text { Turner \& } \\
\text { Hammond (2016) }\end{array}$ & 15 sessions & Individual & $47 y$ & $\begin{array}{l}\text { Man with } \\
\text { Asperger } \\
\text { syndrome }\end{array}$ & $1(\mathrm{M} 1)$ & $\begin{array}{l}\text { RSES } \\
\text { (Rosenberg, } \\
\text { 1965) }\end{array}$ & Effective \\
\hline \multirow[t]{2}{*}{ Mentoring program } & Bradley (2016) & 7-months & Individual $^{\mathrm{f} f}$ & $11 y-12 y$ & $\begin{array}{l}\text { Students } \\
\text { with autism }\end{array}$ & $\begin{array}{l}12 \\
(\mathrm{M} 8, \mathrm{~F} 4)\end{array}$ & $\begin{array}{l}\text { SPPC } \\
\text { (Harter, 1985) }\end{array}$ & Significant \\
\hline & $\begin{array}{l}\text { Curtin, Humphrey, } \\
\text { Vronsky, Mattern, } \\
\text { Nicastro, \& Perrin } \\
(2016)\end{array}$ & $\begin{array}{c}\text { Once a } \\
\text { week for } 2 \\
\text { hours, over } \\
\text { 6-months }\end{array}$ & Individual & $\begin{array}{l}\text { Avg } 15.4 y \\
(\text { Range }=13 y-18 y)\end{array}$ & $\begin{array}{l}\text { Students } \\
\text { with } \\
\text { HFASD }\end{array}$ & $9(\mathrm{M} 7, \mathrm{~F} 2)$ & $\begin{array}{l}\text { RSES } \\
\text { (Rosenberg, } \\
1965 \text { ) }\end{array}$ & Effective \\
\hline \multirow[t]{2}{*}{$\begin{array}{l}\text { Metacognitive training } \\
\text { (Including self- } \\
\text { monitoring) }\end{array}$} & $\begin{array}{l}\text { Goodman, } \\
\text { Corkum, \& } \\
\text { Johnson (2017) }\end{array}$ & 7 sessions & Group & $14 y-17 y$ & $\begin{array}{l}\text { Adolescents } \\
\text { with } \text { ASD }^{\text {d) }}\end{array}$ & 8 & $\begin{array}{l}\text { PHCSCS-2 } \\
\text { (Piers \& } \\
\text { Herzberg, } \\
2002 \text { ) }\end{array}$ & Effective $\left.{ }^{g}\right)$ \\
\hline & Honda (2003) & 7 sessions & Individual & $30 \mathrm{~s}$ & $\begin{array}{l}\text { Man with } \\
\text { Asperger } \\
\text { syndrome }\end{array}$ & $1(\mathrm{M} 1)$ & $\begin{array}{l}\text { Self-esteem } \\
\text { scale (Eagly, } \\
\text { 1967; Honda, } \\
\text { 2003) }\end{array}$ & Effective \\
\hline \multirow[t]{2}{*}{ Social skills training } & $\begin{array}{l}\text { Bruin \& Verheij } \\
\text { (2012) }\end{array}$ & $\begin{array}{c}16 \\
\text { sessions }^{\mathrm{h})}\end{array}$ & Group & $\begin{array}{l}\text { Avg } 8.5 y \\
(S D=0.5)\end{array}$ & $\begin{array}{l}\text { Children } \\
\text { with PDD- } \\
\text { NOS }\end{array}$ & $\begin{array}{l}10 \\
(\mathrm{M} 7, \mathrm{~F} 3)\end{array}$ & $\begin{array}{l}\text { SPPC } \\
\text { (Harter, 1985) }\end{array}$ & Nothing \\
\hline & $\begin{array}{l}\text { Schiltz, McVey, } \\
\text { Dolan, Willar, } \\
\text { Pleiss, Karst, } \\
\text { Carson, Caiozzo, } \\
\text { Vogt, Yund, \& } \\
\text { Hecke (2018) } \\
\end{array}$ & 14 sessions & Group & $\begin{array}{l}\text { Avg } 13.25 y \\
(S D=1.07)\end{array}$ & $\begin{array}{l}\text { Adolescents } \\
\text { with ASD }\end{array}$ & $\begin{array}{l}24 \\
(\mathrm{M} 22, \mathrm{~F} 2)\end{array}$ & $\begin{array}{l}\text { CDI }^{\mathrm{i})} \text { (Carey, } \\
\text { Faulstich, } \\
\text { Gresham, } \\
\text { Ruggiero, } \\
\text { Enyart, 1987) }\end{array}$ & Effective $e^{\mathrm{j})}$ \\
\hline Music intervention & $\begin{array}{l}\text { Hillier, Greher, } \\
\text { Poto, \& Dougherty } \\
(2012)\end{array}$ & 8 sessions & Group & $\begin{array}{l}\left.\text { Avg } 18 y^{c}\right) \\
(\text { Range }=13 y-29 y)\end{array}$ & $\begin{array}{l}\text { Adolescents } \\
\text { and young } \\
\text { adults with } \\
\text { ASD }\end{array}$ & 18 & $\begin{array}{l}\text { RSES } \\
\text { (Rosenberg, } \\
\text { 1989) }\end{array}$ & Significant \\
\hline $\begin{array}{l}\text { Table-talk role-playing } \\
\text { game }\end{array}$ & $\begin{array}{l}\text { Kato \& Fujino } \\
\text { (2016) }\end{array}$ & 5 sessions & Group & $\begin{array}{l}\text { Avg } 14 \mathrm{y} \\
(5 \mathrm{G} \sim \text { Freshman })\end{array}$ & $\begin{array}{l}\text { Children } \\
\text { with ASD }\end{array}$ & $\begin{array}{l}51 \\
(\mathrm{M} 41, \mathrm{~F} 10)\end{array}$ & $\begin{array}{l}\text { Kid-KINDL }^{\circledR} \\
\text { questionnatre } \\
\text { (Bullinger, } \\
\text { 1994; Furusho } \\
\text { et al., 2006) }\end{array}$ & Significant \\
\hline Connections program & $\begin{array}{l}\text { Hillier, Goldstein, } \\
\text { Murphy, Trietsch, } \\
\text { Keeves, Mendes, } \\
\text { \& Queenan (2018) }\end{array}$ & 7 sessions & Group & $\begin{array}{l}\text { Avg } 20.9 y^{c)} \\
(\text { Range }=18 y-28 y)\end{array}$ & $\begin{array}{l}\text { Students } \\
\text { with ASD }\end{array}$ & 26 & $\begin{array}{l}\text { RSES } \\
\text { (Rosenberg, } \\
1989 \text { ) }\end{array}$ & Significant \\
\hline $\begin{array}{l}\text { GOLIAH (Gaming open } \\
\text { library intervention } \\
\text { for autism at home) }\end{array}$ & $\begin{array}{l}\text { Bono, Narzisi, } \\
\text { Jouen, Tilmont, } \\
\text { Hommel, Jamal, } \\
\text { Xavier, Billeci, } \\
\text { Maharatna, Wald, } \\
\text { Chetouani, Cohen, } \\
\text { Muratori, \& } \\
\text { MICHELANGELO } \\
\text { Study Group (2016) }\end{array}$ & 3-months & Individual & $\begin{array}{l}\text { Avg 6.8y } \\
(S D=1.4)\end{array}$ & $\begin{array}{l}\text { Children } \\
\text { with ASD }\end{array}$ & $\begin{array}{l}10 \\
(\mathrm{M} 10)\end{array}$ & $\begin{array}{l}\text { Questionaire } \\
\text { for the parents }\end{array}$ & Effective $e^{\mathrm{j})}$ \\
\hline
\end{tabular}


Trends and Issues in the Self-Esteem of Individuals with Autism Spectrum Disorder

Table 2 Continued

\begin{tabular}{|c|c|c|c|c|c|c|c|c|}
\hline Content & Author & $\begin{array}{l}\text { Term or } \\
\text { frequency }\end{array}$ & $\begin{array}{c}\text { Guidance } \\
\text { type }\end{array}$ & Age or Grade & Participant & Number ${ }^{a)}$ & Scale & Effect $^{\text {b) }}$ \\
\hline $\begin{array}{l}\text { Program which } \\
\text { encourages the } \\
\text { adolescents with } \\
\text { ASD to appreciate } \\
\text { themselves }\end{array}$ & Morita (2012) & 10 sessions & Group & Adolescence & $\begin{array}{l}\text { Adolescents } \\
\text { with ASD }\end{array}$ & 3 (M3) & $\begin{array}{l}\text { RSES } \\
\text { (Rosenberg, } \\
\text { 1965; } \\
\text { Yamamoto, } \\
\text { Matsui, \& } \\
\text { Yamanari, } \\
\text { 1982) }\end{array}$ & Effective \\
\hline $\begin{array}{l}\text { Career education } \\
\text { program }\end{array}$ & Henomatsu (2016) & 12 sessions & Group $^{\mathrm{k})}$ & $\begin{array}{l}\text { Avg 17y } y^{c)} \\
(S D=1.09)\end{array}$ & $\begin{array}{l}\text { Adolescents } \\
\text { with ASD }\end{array}$ & $4(\mathrm{M} 4)$ & $\begin{array}{l}\text { RSES } \\
\text { (Rosenberg, } \\
1965 \text { ) }\end{array}$ & Effective \\
\hline $\begin{array}{l}\text { PEGASUS } \\
\text { (Psychoeducational } \\
\text { programme) }\end{array}$ & $\begin{array}{l}\text { Gordon, Murin, } \\
\text { Baykaner, } \\
\text { Roughan, } \\
\text { Livermore-Hardy, } \\
\text { Skuse, \& Mandy } \\
\text { (2015) }\end{array}$ & 19 sessions & Group & $\begin{array}{l}\text { Avg } 11.74 y \\
(S D=1.66)\end{array}$ & $\begin{array}{l}\text { Young } \\
\text { people with } \\
\text { HFASD }\end{array}$ & $\begin{array}{l}24 \\
(\mathrm{M} 18, \mathrm{~F} 6)\end{array}$ & $\begin{array}{l}\text { RSES } \\
\text { (Rosenberg, } \\
1965)\end{array}$ & Effective \\
\hline
\end{tabular}

Notes. $y=$ year, $\mathrm{G}=$ Grade, Avg=Average, $S D=$ Standard deviation, $\mathrm{M}=$ Male, $\mathrm{F}=\mathrm{Female}$, NS=Not significant, $\mathrm{CDI}=\mathrm{Children}$ 's Depression Inventory, HFPDD=High functioning pervasive developmental disorders, HFASD=High functioning ASD, PDDNOS=Pervasive developmental disorder-not otherwise specified, RSES=Rosenberg Self-Esteem Scale, PHCSCS-2=Piers-Harris Children's Self-Concept Scale-Second Edition, SPPC=Self-Perception Profile for Children

a) If the number of participants was different in the period between the start of the study and the time of measuring the effect, the number of participants at the time of measuring the effect are described.

b) Interventions with statistically significant improvements are described as 'significant', and interventions with improvements after the intervention compared to before are described as 'effective', whereas interventions with no effect are described as 'nothing'.

c) The age or grade of participants at the start of the study.

d) No intellectual disabilities.

e) One of the eight sessions was follow-up-session.

f) A group was composed of four individuals, with one ASD individual and three typically developing individuals. However, because there was only one ASD individual in the group, the group was classified as individual guidance.

g) There were no descriptions of concrete changes in self-esteem through the intervention. However, the graph shows an increase in self-esteem values in five among eight participants. Therefore, it was regarded as showing an intervention effect.

h) Two of the 16 sessions were follow-up-sessions.

i) Negative self-esteem, which is a subscale core, was assessed. The main effects of time and group were non-significant, but the group by time interaction was significant.

j) In the measurement of the effect, $44.4 \%$ of the parents of ASD individuals judged that the intervention was effective. Therefore, it was regarded as demonstrating an effect of the intervention.

k) Although there is no clear description in the text, it was classified based on descriptions such as "Group work for making friends".

others," "Appearance," "Competition," "School competence," "Family support," "Virtue," and "God's love." Sargent, Crocker, and Luhtanen (2006) classified each factor from external or internal perspectives, such that "Approval from others," "Appearance," "Competition," and "School competence (Academics)" were classified as the external contingencies of self-worth, and "Virtue" and "God's love" were classified as the internal contingencies. The assessment of Competencies ("Scholastic Competence," "Athletic Competence,"
"Social Competence," "Physical Appearance," and "Behavioral Conduct") by the SPPC (Harter, 2012a) represents self-evaluations in each domain, whereas the assessment of the external contingencies of selfworth represents the level of the contingencies in the degree to which each factor is associated with selfesteem (Sargent et al., 2006). Therefore, the external contingencies of self-worth are not identical to selfevaluation.

Sargent et al. (2006) indicated that people with the external contingencies of self-worth tend to suf- 
fer from depression, whereas those with the internal contingencies of self-worth do not have this tendency. The internal contingencies of self-worth might be more socially adaptive than external contingencies. Furthermore, Park and Crocker (2005) indicated that "the interpersonal effects of ego threat were caused by threats in a specific domain of contingency." As described above, correlations between the different types of self-esteem and social adaptation in typically developing individuals have been investigated. The self-esteem of ASD individuals should also be examined from different perspectives in the future, and the socially adaptive self-esteem should also be explored.

\section{Necessity for Cross-Sectional and Longitudinal Studies on the Self-Esteem of ASD Individuals}

The 16 articles on self-esteem levels in individuals with ASD that were analyzed in this study consisted of cross-sectional studies, and no longitudinal studies were examined. Moreover, the age range in the 16 studies was limited, and the development of selfesteem was not sufficiently investigated in these studies. Conversely, large-scale cross-sectional studies have been conducted on the self-esteem of typically developing individuals and have indicated certain developmental phases of self-esteem.

Cross-sectional studies on the self-esteem of ASD individuals should be conducted using a sample with a wide age range to clarify the developmental phases of self-esteem by referring to previous research on typically developing individuals (Robins et al., 2002).

Moreover, the development of the self-esteem of ASD individuals and factors related to its development should be investigated through longitudinal studies. As a result of conducting longitudinal studies, longitudinal changes in stability, and self-esteem level, which were suggested by Kernis et al. (1989), would be clarified, and this is expected to lead to the effective support methods of improving self-esteem in ASD individuals.

\section{Necessity for Establishing Effective Support Methods for Improving the Self-Esteem of ASD Individuals}

As described above, the number of articles describing support methods for improving the self-esteem of ASD individuals has been small and insufficient. Identifying effective support methods is crucial for improving the self-esteem of ASD individu- als in the future. Introducing programs such as the "Connections program" developed by Hillier et al. (2018), which focuses on problems that ASD individuals tend to have in their community, might be effective for reducing the frequency and degree of failures and prevent the decline in self-esteem. The different versions of programs based on the developmental stage, such as elementary school, junior high school, senior high school, or university, could also be effective. Kawai et al. (2006) indicated that the higher grades of elementary school is the appropriate period for making intervention to prevent the decline in self-esteem. Support for ASD children to maintain their self-esteem should be started from the upper grades of elementary school.

\section{Acknowledgment}

This paper is a revised revision of the poster presentation at the 5th IASSIDD Europe Congress.

\section{Endnote}

1) A search for "PsycINFO" indicated over 10,000 papers. Therefore, a keyword search was conducted by limiting the search to the "title" or the "abstract."

2) When an article was published on the Internet and in a journal, the date of publication in the journal was regarded as the date of publication.

3) SDs of the self-esteem scores of the ASD group, nephrotic syndrome group, asthma group, and healthy controls were calculated on the basis of the school year from first- to sixth-grade elementary school students. The results indicated that the SDs of the self-esteem scores of the ASD groups in the four among six grades were highest in four groups. Therefore, this study indicated that the SD of the self-esteem score of the ASD group was higher than that of healthy controls.

4) Contingent self-esteem and contingencies of self-worth are identical concepts (Ito, 2016). The former is often used when describing contingent self-esteem suggested by Deci and Ryan (1995), whereas the latter is often used when describing contingent self-esteem suggested by Crocker and Wolf (2001). 


\section{References}

Baumeister, R. F., Campbell, J. D., Krueger, J. I., \& Vohs, K. D. (2003) Does high self-esteem cause better performance, interpersonal success, happiness, or healthier lifestyles? Psychological Science in the Public Interest, 4, 1-44.

Bauminger, N., Shulman, C., \& Agam, G. (2004) The link between perceptions of self and of social relationships in highfunctioning children with autism. Journal of Developmental and Physical Disabilities, 16, 193-214.

Beppu, S. (2010a) Development in the classroom group and selfesteem. In S. Beppu \& M. Kojima (Eds.), Understanding highfunctioning autism: Enhancing self-esteem. Yuhikaku sensho, 131-154. (in Japanese)

Beppu, S. (2010b) Conditions of support for lower and middle grade students in elementary school. In S. Beppu \& M. Kojima (Eds.), Understanding high-functioning autism: Enhancing selfesteem. Yuhikaku sensho, 155-167. (in Japanese)

Bono, V., Narzisi, A., Jouen, A.-L., Tilmont, E., Hommel, S., Jamal, W., Xavier, J., Billeci, L., Maharatna, K., Wald, M., Chetouani, M., Cohen, D., Muratori, F., \& MICHELANGELO Study Group (2016) GOLIAH: A gaming platform for homebased intervention in autism: Principles and design. Frontiers in Psychiatry, 7, 1-16.

Bradley, R. (2016) 'Why single me out?' Peer mentoring, autism and inclusion in mainstream secondary schools. British Journal of Special Education, 43, 272-288.

Bruin, E. I. D. \& Verheij, F. (2012) Social skills training in children with PDD-NOS: An exploratory study. International Journal of Psychiatry in Clinical Practice, 16, 60-67.

Bullinger, M. (1994) KINDL a questionnaire for health-related quality of life assessment in children. Zeitschrift für Gesundheitspsychologie, 1, 64-77.

Capps, L., Sigman, M., \& Yirmiya, N. (1995) Self-competence and emotional understanding in high-functioning children with autism. Development and Psychopathology, 7, 137-149.

Carey, M. P., Faulstich, M. E., Gresham, F. M., Ruggiero, L., \& Enyart, P. (1987) Children's depression inventory: Construct and discriminant validity across clinical and nonreferred (control) populations. Journal of Consulting and Clinical Psychology, 55, 755-761.

Chandler, R. J., Russell, A., \& Maras, K. L. (2018) Compliance in autism: Self-report in action. Autism, 23, 1-13.

Cooper, K., Smith, L. G. E., \& Russell, A. (2017) Social identity, self-esteem, and mental health in autism. European Journal of Social Psychology, 47, 844-854.

Coopersmith, S. (1967) The antecedents of self-esteem. W. H. Freeman and Company, San Francisco.

Crocker, J. \& Wolf, C. T. (2001) Contingencies of self-worth. Psy- chological Review, 108, 593-623.

Curtin, C., Humphrey, K., Vronsky, K., Mattern, K., Nicastro, S., \& Perrin, E. C. (2016) Expanding horizons: A pilot mentoring program linking college/graduate students and teens with ASD. Clinical Pediatrics, 55, 150-156.

Deci, E. L. \& Ryan, R. M. (1995) Human autonomy: The basis for true self-esteem. In M. H. Kernis (Ed.), Efficacy, agency, and self-esteem. Plenum Press, New York, 31-49.

Donnellan, M. B., Trzesniewski, K. H., Robins, R. W., Moffitt, T. E., \& Caspi, A. (2005) Low self-esteem is related to aggression, antisocial behavior, and delinquency. Psychological Science, 16, 328-335.

Eagly, A. H. (1967) Involvement as a determinant of response to favorable and unfavorable information. Journal of Personality and Social Psychology, 7, 1-15.

Endo, Y. (2013) Self-esteem. In T. Fujinaga (Ed.), New encyclopedia of psychology. Heibonsha, Tokyo, 287-290. (in Japanese)

Furusho, J., Kubagawa, T., Satoh, T., Shibata, R., Nemoto, Y., Matsuzaki, K., Sone, M., \& Watanabe, S. (2006) A study of the Kid-KINDL ${ }^{\circledR}$ Questionnaire scores for children with developmental disorders in normal classes and their parents. No To Hattatsu, 38(S1), 183-186.

Goddard, L., O’Dowda, H., \& Pring, L. (2017) Knowing me, knowing you: Self defining memories in adolescents with and without an autism spectrum disorder. Research in Autism Spectrum Disorders, 37, 31-40.

Goodman, L. R., Corkum, P., \& Johnson, S. A. (2017) A metacognitive training pilot study for adolescents with autism spectrum disorder: Lessons learned from the preliminary stages of intervention development. Journal of Intellectual \& Developmental Disability, 42, 204-210.

Gordon, K., Murin, M., Baykaner, O., Roughan, L., LivermoreHardy, V., Skuse, D., \& Mandy, W. (2015) A randomised controlled trial of PEGASUS, a psychoeducational programme for young people with high-functioning autism spectrum disorder. Journal of Child Psychology and Psychiatry, and Allied Disciplines, 56, 468-476.

Happé, F. G. (1995) The role of age and verbal ability in the theory of mind task performance of subjects with autism. Child Development, 66, 843-855.

Harris, M. A., Donnellan, M. B., \& Trzesniewski, K. H. (2017) The lifespan self-esteem scale: Initial validation of a new measure of global self-esteem. Journal of Personality Assessment, 1, $84-95$.

Harter, S. (1982) The perceived competence scale for children. Child Development, 53, 87-97.

Harter, S. (1985) Manual for the self-perception profile for children. University of Denver, Denver.

Harter, S. (1988) Manual for the self-perception profile for adoles- 
cents. University of Denver, Denver.

Harter, S. (2012a) Self-perception profile for children: Manual and questionnaires. University of Denver. https://portfolio. du.edu/SusanHarter/page; 44210 (Retrieved February 11, 2019)

Harter, S. (2012b) Self-perception profile for adolescents: Manual and questionnaires. University of Denver. https://portfolio.du.edu/SusanHarter/page; 44210 (Retrieved February 11, 2019)

Henomatsu, K. (2016) Practical study of carrier education program for students with autism spectrum disorder. Bulletin of Den-en Chofu University, 11, 219-228. (in Japanese)

Hesselmark, E., Plenty, S., \& Bejerot, S. (2014) Group cognitive behavioural therapy and group recreational activity for adults with autism spectrum disorders: A preliminary randomized controlled trial. Autism, 18, 672-683.

Hillier, A., Goldstein, J., Murphy, D., Trietsch, R., Keeves, J., Mendes, E., \& Queenan, A. (2018) Supporting university students with autism spectrum disorder. Autism, 22, 20-28.

Hillier, A., Greher, G., Poto, N., \& Dougherty, M. (2012) Positive outcomes following participation in a music intervention for adolescents and young adults on the autism spectrum. Psychology of Music, 40, 201-215.

Honda, K. (2003) A case study of behavioral modification by selfmonitoring for borderline mental retardation person: Effective treatment elements for decreasing anxiety and effect of behavior modification to self-esteem. Japanese Journal of Behavioral Medicine, 9, 31-35. (in Japanese)

Ichikado, K., Sumio, K., \& Abe, H. (2008) A study on self esteem in individuals with mild developmental disorders: Analysis of data from the self-esteem scale and the KU competence scale. Visio, 37, 1-7. (in Japanese)

Inoue, N. (1985) Relation between self-esteem of female adolescents and their motives as well as inferiority complex. Future Prospects of Educational Evaluation, 5, 68-81.

Inoue, N. (1986) Relation between child's self-esteem and response to unsuccessful problems. Japanese Journal of Educational Psychology, 34, 10-19. (in Japanese)

Ito, M. (2016) Self-esteem and sense of authenticity: Both are important. In R. Nakama (Ed.), Psychology of self-esteem: A manual for deepening understanding. Kanekoshobo, Tokyo, 35-47. (in Japanese)

Ito, M. \& Kodama, M. (2005) Sense of authenticity, self-esteem, and subjective and psychological well-being. Japanese Journal of Educational Psychology, 53, 74-85. (in Japanese)

Jamison, T. R. \& Schuttler, J. O. (2015) Examining social competence, self-perception, quality of life, and internalizing and externalizing symptoms in adolescent females with and without autism spectrum disorder: A quantitative design including between-groups and correlational analyses. Molecular Autism, 6, 53 .

Kajita, E. (1980) Psychology of self-consciousness. University of Tokyo Press, Tokyo. (in Japanese)

Kato, K. \& Fujino, H. (2016) Does the TRPG activity enhance QOL in children with ASD? Bulletin of Tokyo Gakugei University. Division of Educational Sciences, 67, 215-221. (in Japanese)

Kawai, E., Yoshida, T., Miyamoto, H., \& Yamanaka, K. (2006) Evaluation of a training program to prevent deterioration of children's self-esteem: Fostering children's skills in arguing against self-defeating cognitions about negative events. Japanese Journal of Educational Psychology, 54, 112-123. (in Japanese)

Kernis, M. H. (2003) Toward a conceptualization of optimal selfesteem. Psychological Inquiry, 14, 1-26.

Kernis, M. H., Grannemann, B. D., \& Barclay, L. C. (1989) Stability and level of self-esteem as predictors of anger arousal and hostility. Journal of Personality and Social Psychology, 56, 1013-1022.

Kojima, M. (2012) Education for self-concept of children with developmental disabilities. Japanese Journal of Developmental Disabilities, 34, 6-12. (in Japanese)

Kojima, M. \& Noutomi, K. (2013) Self-esteem, self-evaluation, and social-support for children with high functional pervasive developmental disabilities in forth to sixth grade of elementary school. Japanese Journal of Learning Disabilities, 22, 324-334. (in Japanese)

Koyasu, M. (2013) Developmental stage. In T. Fujinaga (Ed.), New encyclopedia of psychology. Heibonsha, Tokyo, 624-625. (in Japanese)

Locke, J., Ishijima, E. H., Kasari, C., \& London, N. (2010) Loneliness, friendship quality and the social networks of adolescents with high-functioning autism in an inclusive school setting. Journal of Research in Special Educational Needs, 10, 74-81.

Maeshiro, K. (2000) Structure of the self esteem in childhood. The Study of Applied Sociology, 10, 63-82. (in Japanese)

Maras, K. L. \& Bowler, D. M. (2012) Brief report: Suggestibility, compliance and psychological traits in high-functioning adults with autism spectrum disorder. Research in Autism Spectrum Disorders, 6, 1168-1175.

Marsh, H. W. (1992) Self Description Questionnaire II: SDQ II; Manual. Faculty of Education, University of Western Sydney, New South Wales.

Mazurek, M. O. (2014) Loneliness, friendship, and well-being in adults with autism spectrum disorders. Autism, 18, 223-232.

McCauley, J. B., Harris, M. A., Zajic, M. C., Swain-Lerro, L. E., Oswald, T., McIntyre, N., Trzesniewski, K., Mundy, P., \& Solomon, M. (2017) Self-esteem, internalizing symptoms, and the- 
ory of mind in youth with autism spectrum disorder. Journal of Clinical Child and Adolescent Psychology, 53, 1-12.

McChesney, G. \& Toseeb, U. (2018) Happiness, self-esteem, and prosociality in children with and without autism spectrum disorder: Evidence from a UK population cohort study. Autism Research, 11, 1011-1023.

Miyachi, K. \& Kojima, M. (2013) Self-esteem, self-evaluation and depression in children with high functional pervasive developmental Disabilities. Annual Report of The Faculty of Education, Gifu University. Humanities and Social Sciences, 62, 175-181. (in Japanese)

Morita, M. (2012) On a program which encourages the adolescents with autistic spectrum disorder to appreciate themselves. Research-Aid Paper of the Yasuda Life Welfare Foundation, 48, 105-113. (in Japanese)

Nagai, Y., Uemura, O., Kaneko, T., Kanda, Y., Gotoh, Y., Nakagawa, M., Uzuyama, S., Nomura, K., \& Iwasa, M. (2018) Self-perception of children with autism spectrum disorders. Minerva Pediatrica, 70, 12-19.

Nakama, R. (2013) Reevaluating the relation between self-esteem and psychological well-being: The concept of "Blessed SelfFeeling”. Japanese Journal of Educational Psychology, 61, 374386. (in Japanese)

Nomura, K., Beppu, S., \& Tsujii, M. (2012) Loneliness in children with high functioning pervasive developmental disorders. Japanese Journal of Special Education, 49, 645-656.

Oka, K. \& Ono, J. (2010) The investigations of self-evaluation and self-recognition in children with high-functioning pervasive developmental disorders: Through the self-perception profile for children and semi-structured interview. The Japanese Journal of Autistic Spectrum, 8, 39-48. (in Japanese)

Ota, M. \& Nagasawa, T. (2004) Developmental features of the self-esteem of children who stutter: Comparison with the selfesteem of children who do not stutter. Japanese Journal of Special Education, 42, 259-270. (in Japanese)

Park, L. E. \& Crocker, J. (2005) Interpersonal consequences of seeking self-esteem. Personality and Social Psychology Bulletin, 31, 1587-1598.

Piers, E. V. \& Herzberg, D. S. (2002) Manual for the Piers-Harris Children's Self-Concept Scale, 2nd edition. Western Psychology Services, Los Angeles.

Robins, R. W., Trzesniewski, K. H., Tracy, J. L., Gosling, S. D., \& Potter, J. (2002) Global self-esteem across the life span. Psychology and Aging, 17, 423-434.

Rosenberg, M. (1962) The association between self-esteem and anxiety. Journal of Psychiatric Research, 1, 135-152.

Rosenberg, M. (1965) Society and the adolescent self-image. Princ- eton University Press, Princeton, New Jersey.

Rosenberg, M. (1989) Society and the adolescent self-image: Revised edition. Wesleyan University Press, Middletown.

Sakurai, S. (1983) Development of the Japanese edition of the Harter's perceived competence scale for children. The Japanese Journal of Educational Psychology, 31, 245-249. (in Japanese)

Sakurai, S. (1992) The investigation of self-consciousness in the 5th-and 6th-grade children. Japanese Journal of Experimental Social Psychology, 32, 85-94. (in Japanese)

Sargent, J. T., Crocker, J., \& Luhtanen, R. K. (2006) Contingencies of self-worth and depressive symptoms in college students. Journal of Social and Clinical Psychology, 25, 628-646.

Schiltz, H. K., McVey, A. J., Dolan, B. K., Willar, K. S., Pleiss, S., Karst, J. S., Carson, A. M., Caiozzo, C., Vogt, E. M., Yund, B. D., \& Hecke, A. V. V. (2018) Changes in depressive symptoms among adolescents with ASD completing the PEERS ${ }^{\circledR}$ social skills intervention. Journal of Autism and Developmental Disorders, 48, 834-843.

Spain, D. \& Blainey, S. H. (2017) Enhancing self-esteem in adults with autism spectrum disorders: A pilot cognitive behaviour therapy (CBT) group intervention. Advanced in Autism, 3, 66-75.

Tanaka, M., Hirosawa, M., Takiyoshi, M., \& Yamazaki, T. (2006) Development of self-consciousness in children with developmental disorders such as attention-deficit/hyperactivity disorder and high-functioning pervasive developmental disorders: From the viewpoint of questioning themselves and being informed of their disorders. Annual Report Graduate School of Education. Tohoku University, 54, 431-443. (in Japanese)

Turner, M. A. \& Hammond, N. (2016) Cognitive behavioural therapy in the treatment of social skills deficits and social phobia in a man with an autism spectrum disorder: A single-case study. Cognitive Behaviour Therapy, 9, 1-15.

Volkmar, F. R., Sparrow, S. S., Goudreau, D., Cicchetti, D. V., Paul, R., \& Cohen, D. J. (1987) Social deficits in autism: An operational approach using the Vineland Adaptive Behavior Scales. Journal of the American Academy of Child and Adolescent Psychiatry, 26, 156-161.

Williamson, S., Craig, J., \& Slinger, R. (2008) Exploring the relationship between measures of self-esteem and psychological adjustment among adolescents with Asperger syndrome. Autism, 12, 391-402.

Yamamoto, M., Matsui, Y., \& Yamanari, Y. (1982) The structure of perceived aspects of self. Japanese Journal of Educational Psychology, 30, 64-68. (in Japanese)

Zeigler-Hill, V. (2013) The importance of self-esteem. In V. Zeigler-Hill (Ed.), Self-esteem. Psychology Press, New York, 1-20. 